\title{
The ImPaCt OF MARKet Focus ON OPERATIONS Practices
}

\author{
Tritos Laosirihongthong \\ Department of Industrial Engineering \\ Thammasat University \\ Klong Luang, Pathumtanee 12121, Thailand \\ Phone: 66-81-615-8616 \\ Email: Itritos@engr.tu.ac.th \\ Keah Choon Tan* \\ Department of Management \\ University of Nevada, Las Vegas \\ Las Vegas, NV 89154-6009, USA \\ Tel: (702) 895-3873 \\ kctan@unlv.edu \\ Vijay R. Kannan \\ Jon M. Huntsman School of Business \\ Utah State University \\ Logan, UT 84322-3555, USA \\ Phone: (435) 797-7212 \\ Email:v.kannan@usu.edu
}

(Original Manuscript \# TPRS-2008-IJPR-1021)

Prepared for Resubmission to the International Journal of Production Research

(* corresponding author)

May 12, 2009 


\title{
The IMPACT OF MARKet Focus ON OPERATIONS Practices
}

\begin{abstract}
A key element of successful organizations is the alignment of their strategy and tactics. This study explores the relationship between a firm's competitive strategy and its operations practices in the context of a developing economy. Two competitive strategies are examined; a niche market strategy characterized by targeting specific market segments, and a broad market strategy characterized by serving a wide range of market segments. Three sets of operations practices consistent with the adoption of lean manufacturing, total quality management, and relationship development in a supply chain context, are explored. Using survey data from senior managers in Thailand, results show that for firms adopting a niche market strategy, competitive strategy directly influences process management and relationship development, which in turn affect workforce commitment. Only workforce commitment has a direct influence on operational performance. In contrast, for firms adopting a broad market strategy, competitive strategy directly influences workforce commitment, which in turns influences process management and relationship development practices. It is the latter practices that directly influence operational performance.
\end{abstract}

Keywords: Competitive Strategy, Market Focus, Process Management, Workforce Commitment, Relationship Building, Operational Performance, Empirical Study, Cluster Analysis. 


\section{INTRODUCTION}

The notion that competitive strategy is formulated at the top of the firm but executed from the bottom up amplifies the need to align operations strategy with competitive strategy (Shah and Ward, 2007). While vision, planning, and directives flow from senior leadership, individuals at all levels of the firm must act in concert to ensure that high level objectives are achieved. Alignment between competitive and operations strategies is thus vital to the effective execution of strategic plans and the enhancement of business performance. Unfortunately, many firms fail to allocate resources in a manner consistent with competitive strategy, a fact discussed in the operations strategy literature as early as 1969 (Skinner, 1969) but which continues to be a prevailing theme (e.g., Swink et al., 2005, Brown et al, 2007, Karim et al., 2008). In recent years, the challenge has been compounded by a changing business landscape characterized by complex organizational structures, globalization, new regulations, and the pressure to innovate rapidly. Successful creation and execution of competitive strategy requires not only the vision and commitment of top management but a consistent operations strategy, particularly as it relates to processes, human resources, and supply chain relationships.

Companies are increasingly restructuring their processes, human resources, and supply chain practices to be consistent with evolving long-term company objectives. Operations practices alone are insufficient to sustain a firm's competitive edge. Similarly, competitive strategy does not equate to competitiveness absent matching processes, human resource practices, and effective relationships with supply chain members. Linkages between competitive strategy and operations strategy have been studied widely (e.g., Ward and Duray, 2000, Fynes et al, 2005, Brown et al, 2007). However, the effect of the alignment between competitive strategy 
and operations strategy, and in particular how operations strategy is deployed via specific practices, on firm performance has received relatively less attention.

One dimension of competitive strategy is the choice of markets to serve, commonly referred to as market focus. We explore the relationship between a firm's market focus as it relates to the breadth of markets and customers it serves, operations practices, and operational performance. Two market foci are examined; a niche market focus characterized by targeting specific customer/market groups, and a broad market focus characterized by serving a broad range of customers and market segments (Liao and Cheung, 2002). Three sets of operations practices consistent with the philosophy of continuous improvement are examined; process management practices based on lean manufacturing principles (Shah and Ward, 2003), workforce related practices consistent with the principles of total quality management (Rahman and Bullock, 2005), and inter-organizational relationship development practices based on the underlying premise of supply chain management to leverage information and goods/services flows (Tan, 2001). All three are consistent with the notion that sustainable value creation depends not only on improving internal processes - both technical and social - but on building the necessary infrastructure with suppliers that enables them to serve the needs of the focal firm.

\section{LITERATURE REVIEW}

\section{Manufacturing Strategy, Competitive Strategy, and Market Focus}

Firms implement a variety of competitive strategies to achieve advantage in the market place. Porter (1980) defined focus as one such strategy, referring to it as the strategic choice to focus on a specific type of customer, product, or geographic market. Miller (1988) contended 
that rather than representing a particular strategic orientation, focus can be characterized as a continuum, making the distinction between a niche market and a broad market focus. The choice of competitive strategy based on a niche versus a broad market focus has important implications for operations practices since the latter must act in concert with the firm's competitive strategy. Within the manufacturing strategy literature, the notion of aligning manufacturing strategy with corporate and marketing strategy has a long history (e.g., Hayes and Schmenner, 1978, Hayes and Wheelwright, 1979). Several articles have also explored the issue of market focus. Bozarth (1993) characterized market focus as the consistency of product demand on a plant. The implication was that a consistent, limited set of demands on a plant, whether based on product characteristics or customer preferences, has a positive impact on manufacturing consistency and performance. A conceptual model revealed two key results related to market focus. First, market focus is positively related to manufacturing performance (Bozarth and Edwards, 1997, Bozarth and McCreery, 2001). In particular, the number of major customers served and product lines offered by a plant are inversely correlated with manufacturing performance. Second, increases in focus are positively correlated with increases in performance (Bozarth and McCreery, 2001).

Ward and et al. (1996) identified characteristics of manufacturing strategy consistent with niche and broad market focused strategies. Building on prior research, they argued that niche focused firms maintain flexibility to respond to environmental change and the need for product customization. In contrast, broad market focused firms need to maintain both flexibility and output predictability. Liao and Cheung (2002) explored differences between broad and narrowly focused strategies with respect to technology deployment. They found that firms with a broad 
market focus emphasized leveraging research and development more than those with a narrow market focus.

\section{Strategy and Practice}

The implication of prior research is that choices regarding competitive strategy drive manufacturing strategy. A corollary is that competitive strategy influences choices regarding specific manufacturing practices. This will in turn influence manufacturing performance. Our focus is on three sets of manufacturing practices that, according to prior research, drive performance; process management based on the philosophy of lean manufacturing, workforce commitment, and relationship development in the supply chain. These practices are consistent with established manufacturing and quality improvement models. Moreover, according to a recent study of lean manufacturing practices (Shah and Ward, 2007), they transcend manufacturing philosophies such as Total Quality Management (TQM), Just in Time (JIT), and the Toyota Production System (TPS). Several empirical studies have also explored relationships between TQM, JIT, and supply chain management practices, supporting the assertion that the dimensions of interest are core to the execution of manufacturing strategy. Flynn et al. (1995a), for example found TQM and JIT practices to be not only mutually supportive, but that their synergy contributed positively to performance. The constructs in their study included workforce management, supplier relationships, and setup time and lot size reductions. Sakakibara et al. (1997) suggested that JIT practices affect performance as a result of the strategic, quality focused infrastructure needed to support them. The infrastructure they described again included the dimensions of workforce management, setup time reduction, the use of maintenance, and supplier relationships. Kannan and Tan (2005) not only found positive correlations between a 
firm's adoption of TQM and JIT practices in the context of managing their supply chains, they demonstrated the presence of direct relationships between practices and performance. Items they considered included those related to setup and lot size reductions, maintenance, workforce training and empowerment, and the development of relationships within the supply chain. In summary, regardless of the paradigm driving manufacturing strategy, process management, workforce commitment, and supply chain relationship development appear to be common themes.

The literature on lean manufacturing dates back three decades, typically under the guise of JIT. While the expressions JIT and lean manufacturing are often used synonymously, JIT is in fact a subset of the broader lean manufacturing philosophy. Indeed, the early focus on the JIT dimension of the Toyota Production System which underlies lean manufacturing, has led, in the U.S. context, to JIT being viewed as being the system itself (Womack et al., 1990, Shah and Ward, 2007). In reality, JIT is but one lean practice identified from a review of key literature on high performance/lean/JIT manufacturing systems (Shah and Ward, 2003). Of twenty one practices identified, several, including quick changeover techniques, preventive maintenance, and process reengineering, relate directly to daily management of the manufacturing process, and ensuring its integrity. Several articles, drawn primarily from the literature on JIT systems, have empirically showed that these practices, used as part of a broader execution strategy, can positively impact various measures of manufacturing and financial performance (e.g., Flynn et al., 1995a, Nakamura et al., 1998, Fullerton and McWatters, 2001).

Research on quality management distinguishes between soft and hard elements of TQM (Rahman and Bullock, 2005). Elements of soft TQM are typically human resource related, such as 
commitment and teamwork, whereas elements of hard TQM are typically process related, such as preventive maintenance and modular designs. The literature is replete with evidence that both are critical components of a cohesive improvement program (e.g., Anderson et al., 1995, Flynn et al., 1995b, Samson and Terziovski, 1999). It is sometimes argued that soft TQM practices affect performance indirectly. By creating an environment conducive to the seamless diffusion and implementation of hard TQM practices, soft TQM practices affect operational performance in a way similar to that of traditional human resource management practices (e.g., Kochan et al., 1995). Indeed, Rahman and Bullock (2005) argued that it is appropriate to first investigate the direct impact of soft TQM on the diffusion of hard TQM, before assessing the subsequent impact of hard TQM on operational performance. Their study showed positive relationships between soft and hard elements of TQM, and indirect relationships between soft TQM practices and performance.

Several studies have highlighted the importance of relationships in effectively leveraging supply chain partnerships in support of achieving competitive edge (e.g., Carr and Pearson, 1999, Martin and Grbac, 2003, Kannan and Tan, 2005). By leveraging supplier capabilities, firms not only exploit supplier expertise but focus on their own core competencies. While an extensive literature base, drawn from both the purchasing and logistics dimensions of the supply chain, exists, evidence of linkages between supply chain practices and strategy is limited.

While lean manufacturing, TQM, and supply chain management have been shown to be important dimensions of manufacturing strategy, evidence of the relationship between specific practices within each of these dimensions and competitive strategy, is limited. Specifically, there is little evidence of their relationships with niche and broad market focused strategies. Ward et 
al., (1996) identified several desirable attributes of manufacturing strategy and manufacturing choices associated with niche and broad market based competitors, but stopped short of addressing tactics. Our objective is to address this gap in the literature by examining the relationship between competitive strategy, manufacturing strategy, and operational performance in the context of Thailand.

The ASEAN region, and in particular Thailand, is an area with significant potential for growth and development (Wang and Chien, 2007). Rising production costs and shrinking product life cycles have forced many multinational corporations from the United States, European Union, and Japan to relocate their manufacturing facilities to Thailand to exploit low labor costs, proximity to raw materials, and new consumer markets (Phusavat and Kanchana, 2008). The economic importance, drive for global competitiveness, and growth potential of Thailand make

it a compelling area for academic research. Little has been written about the role of manufacturing strategy in developing economies, and in particular, Thailand. However recent articles are beginning to highlight the challenges manufacturers in these environments face (Laosirihongthong et al., 2003, Laosirihongthong and Dangayach, 2005).

\section{ReseARCh Model ANd Hypotheses}

We propose that market focus oriented competitive strategy drives operations strategy as executed through processes, human resources, and supplier relationships (Figure 1). To attain sustainable competitive advantage, firms must formulate and execute an operations strategy that exploits its unique capabilities in processes, human resources, and supplier relationships. This must however reflect the strategic orientation of the firm in the marketplace, whether it 
seeks to serve a broad base of customers or more narrowly defined customer segments. Specifically, we test the hypotheses

$H_{1}$ : For firms with a niche market focus, process management, workforce commitment, and relationship development practices directly affect operational performance.

$\mathrm{H}_{2}$ : For firms with a broad market focus, process management, workforce commitment, and relationship development practices directly affect operational performance.

Insert Figure 1

\section{SuRVey Instrument AND ReSPONDENt PROFile}

\section{Survey Instrument}

Pre-tested constructs from past empirical studies were used to ensure the validity and reliability of the survey instrument (Tata et al., 1999). The process management scale was adapted from Shah and Ward (2003), and included key elements of lean implementation; total preventive maintenance, JIT, and single minute exchange of dies (Womack et al., 1990, Shah and Ward, 2003). Specifically, the scale included items on preventive maintenance, cycle time reduction, use of new process equipment or technologies, quick changeover techniques, and error proofing/Poka-Yoke. The workforce commitment scale (soft TQM) was derived from Rahman and Bullock (2005). It captured several key aspects of soft TQM components such as internal communication, involvement of employees, and training and education. These elements address not only TQM implementation but a firm's commitment to developing an organizational culture consistent with quality-oriented behavior (Anderson et al., 1995, Dow et al., 1999). The relationship development scale was adapted from Tan (2002) and includes the desire to 
determine customers' future expectation and needs, establishing close and good relationship with suppliers and customers, information sharing/communication, and the involvement of customers and suppliers. The scale reflects inter-organizational relationship development practices consistent with the underlying premise of developing relationships to leverage information sharing (Davis, 1993, Power et al., 2001, Kannan and Tan, 2005).

The market focus construct was adapted from Liao and Cheung (2002). The niche market focus scale incorporates three items that target product development with a focus on value added, low cost, and differentiation to meet specific market segments. The scale for broad market focus includes similar items but is oriented to a wide range of commercial and industrial uses for a broad market segment. To measure operational performance, criteria used in previous empirical studies in the TQM, supply chain management, and lean production literature were adapted (e.g., Kannan and Tan, 2005, Rahman and Bullock, 2005). Performance measures such as on time delivery, production efficiency, and customer satisfaction were used.

Constructs used in this research were measured using five-point Likert scales (Appendix). Competitive strategy, process management, workforce commitment, and relationship development practices were measured by the extent of implementation of the corresponding item ("not at all" [1] to "to a great extent" [5]) whereas operational performance was measured based on comparisons with industry peers ("lowest" [1] to "highest" [5]).

\section{Data Collection}

Survey data was collected from manufacturing companies in Thailand. The manufacturing sector in Thailand is heterogeneous in terms of sub-sectors and product/process complexity. The literature has shown that the three sets of operations practices of interest to this study have 
been widely implemented in Thailand, particularly in the automobile parts and components, electronics, electrical appliances, textiles, and food sectors (Laosirihongthong and Dangayach, 2005). Data collection was conducted in three stages. In the first stage, 270 survey questionnaires were administered to participants of training courses organized by the Thai-Japan Technology Promotion Association, the largest training organization in Thailand. These courses focused on manufacturing strategy, operational excellence, and continuous improvement. Participants were mid or senior managers from a cross section of manufacturing firms. A total of 215 questionnaires were completed and returned within a week of completing the course. In the second stage, 85 questionnaires were administered to graduate students enrolled in the International Executive MBA program at Thammasat University, a leading Southeast Asian university located in Bangkok. Students were industry professionals with several years of work experience in manufacturing. Seventy completed responses were received. In the third stage, 75 questionnaires were administered to graduate students enrolled in the Masters of Engineering Program at Thammasat University. Only students who had several years of work experience in multinational manufacturing firms were invited to participate in the study, thus a relatively small sample of 44 surveys were returned. A total of 329 usable cases were collected, resulting in an overall response rate of 76.5\%. A profile of respondents is presented in Table 1.

Insert Table 1 


\section{Statistical Analyses}

\section{Reliability Analysis and Factor Analysis}

Validity and reliability tests were conducted for the six constructs (Tables $2-7$ ). Reliability analysis was conducted by examining the value of Cronbach's $\alpha$ (Cronbach, 1951) for each construct. Results showed that in each case, values of $\alpha$ exceeded the suggested threshold value of 0.6 (Nunnally, 1988). Since Cronbach's a may under-estimate errors caused by external factors such as differences in testing situations and respondents over time, composite reliability and average variance extracted were also examined since they are more parsimonious measure of reliability (Podsakoff et al., 2003). Statistics for composite reliabilities for the six constructs exceeded the required threshold value of 0.60 , providing further evidence of scale reliability. All average variances extracted also exceeded the threshold level of 0.50 .

Principal components analysis using Varimax rotation was used to examine the unidimensionality of the constructs. Factor loadings of all items within each scale were above 0.70 , providing support for the validity of measuring the latent variables using the respective sets of indicators. Values of the Kaiser-Meyer-Olkin Measure of Sampling Adequacy (KMO) in excess of 0.50 (Kaiser, 1974) indicated that the use of factor analysis was appropriate, and that extracted factors were distinct and reliable. This is re-affirmed by the fact that for each scale, Bartlett's Sphericity Test for the null hypothesis that the correlation matrix is an identity matrix, was rejected $(\alpha=5 \%)$. 
Insert Tables $2-7$

\section{Hierarchical Cluster Analysis and Multiple Linear Regression}

Hierarchical cluster analysis was used on the premise that firms could be separated into two distinct clusters based on market focus. The two factor scores extracted from the six measured variables (Appendix, A2, A4, A6 versus $A 1, A 3, A 5$ ) were used to cluster the cases. The first cluster yielded 185 cases (57.6\%) and the second yielded 136 cases (42.4\%, Table 8). Eight cases were discarded due to missing responses in the market focus questions A1 to A6.

Insert Table 8

Independent samples t-tests were used to examine the focus of each cluster. Levene's test showed that variances between the two clusters were equal. Firms in cluster one (indicators A2, $A 4$, and A6) yielded higher group mean values than those in cluster two (indicators $A 1, A 3$, and A5). This is consistent with these firms having a niche market focus. Similarly, firms in cluster two yielded higher group mean values than those in cluster one. This is consistent with these firms having a broad market focus (Table 9). Table 10 presents descriptive statistics of each indicator for each cluster. 
Insert Table 9

Insert Table 10

Multiple linear regression was used to examine relationships between operations practices and operational performance for each cluster. The hierarchical multiple regression model for the Niche Market Focus cluster was statistically significant $(\alpha=5 \%$ ), with $25.1 \%$ of variation in the data explained by the model (Table 11). However, only workforce commitment $(\beta=.386)$ yielded a significant relationship with operational performance, hence hypothesis $\mathrm{H}_{1}$ is only partially supported. The model for the Broad Market Focus cluster was again significant, with $34.5 \%$ of variation in the data explained by the model. Interestingly, this model exhibited significant relationships between performance and both process management and relationship development. However, there was no significant relationship between performance and workforce commitment. Hence, hypothesis $\mathrm{H}_{2}$ was also only partially supported.

\section{Insert Table 11}

The absence of significant relationships between either process management or relationship development and operational performance for Niche Market Focus firms, and between workforce commitment and performance in Broad Market Focus firms, is inconsistent with the literature. The literature consistently demonstrates that these constructs are positively related to performance (Bozarth and Edwards, 1997, Sakakibara et al. (1997), Bozarth and McCreery, 
2001, Kannan and Tan, 2005). However, the literature has not used market focus as a contingency variable, nor has it made the distinction between direct and indirect relationships. To explore these issues, a structural equation model was used to examine whether relationships between these variables and performance might be indirect. Since process management and relationship development were insignificant in the linear regression model for firms with a Niche Market Focus, we suspect that they influence operational performance indirectly via workforce commitment. This is true in a job shop environment where highly skilled labor is required to produce specific products to meet the demands of a niche market, using small lot sizes and a wide range of general purpose equipment. General purpose equipment supports the workforce, but it is the workers that directly affect performance. Moreover, close and cooperative relationships with suppliers are crucial in correctly determining their needs. Similarly, the insignificant relationship between workforce commitment and operational performance for firms with a Broad Market Focus may be due to workforce commitment influencing performance indirectly via process management and relationship management. Thus, the following additional hypotheses were examined:

$H_{3}$ : A Niche Market Focus affects process management and relationship development.

$\mathrm{H}_{4}$ : For firms with a Niche Market Focus, process management and relationship development affect operational performance indirectly via workforce commitment.

$H_{5}$ : A Broad Market Focus affects workforce commitment.

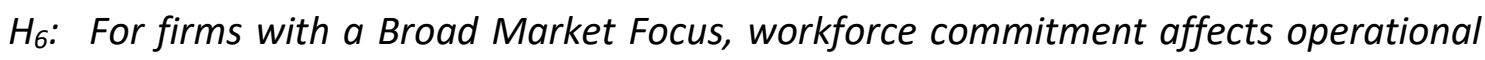
performance indirectly via process management and relationship development.

Figure 2 summarizes hypotheses $\mathrm{H}_{3}$ to $\mathrm{H}_{6}$. 
Insert Figure 2

\section{Structural Equation Modeling}

The two-stage structural equation modeling technique was used (Anderson and Gerbing, 1988). Each measurement model was tested prior to testing the structural equation model. Measurement models address the reliability and validity of indicators in measuring latent variables or hypothetical constructs, thereby providing an assessment of convergent and discriminant validity. The structural model specifies direct and indirect relations among latent variables and describes the amount of explained and unexplained variance in the model. Moreover, it gives an assessment of predictive validity. Models were checked to ensure parameter estimates exhibited the correct sign and size, and were consistent with underlying theory. All parameters shown were statistically significant $(\alpha=0.05)$. The $\chi^{2} / \mathrm{df}$ statistics and other fit indices in Table 12 indicated that the structural equation models fit the sample data well (Anderson and Gerbing, 1988).

Results provide support for hypotheses $\mathrm{H}_{3}$ and $\mathrm{H}_{4}$. The structural equation model for the Niche Market Focus cluster (Figure 3) shows that market focus directly affects process management $(\gamma=.89)$ and relationship development $(\gamma=.70)$, which subsequently affects operational performance via workforce commitment $(\beta=.58)$. For the Broad Market Focus cluster (Figure 4), market focus directly affects workforce commitment $(\gamma=.60)$, which subsequently affects operational performance via both process management $(\beta=.22)$ and relationship development $(\beta=.57)$. This provides support for hypotheses $H_{5}$ and $H_{6}$. These results 
suggest that the relationship between operations strategy and operational performance is a function of market focus, and that workforce commitment appears to be the link between strategy and operational performance.

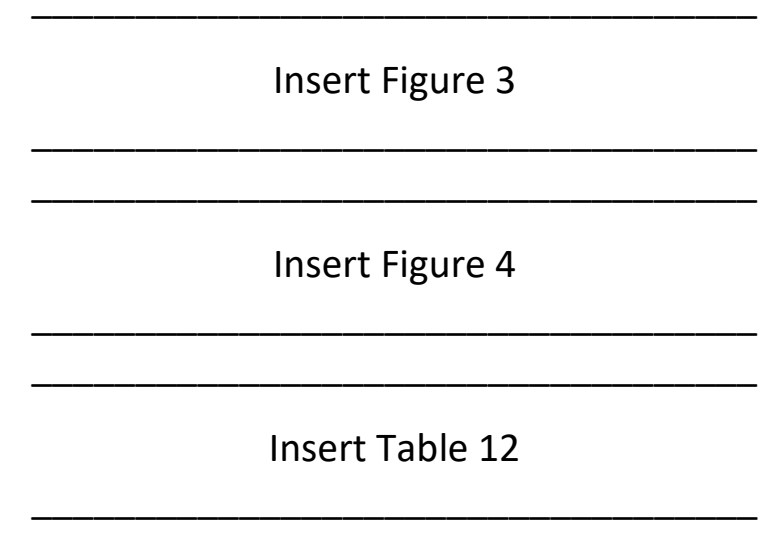

\section{DISCUSSION AND MANAGERIAL IMPLICATIONS}

The underlying premise of the study was that the influence of competitive strategy on operational performance for manufacturing firms in Thailand comes by virtue of how strategy is deployed via operations practices. Partial support for hypotheses $\mathrm{H}_{1}$ and $\mathrm{H}_{2}$ demonstrates that operations practices affect operational performance differently for manufacturing firms with a niche rather than a broad market focus. Of greater significance however are the results of the structural equation models and subsequent support for hypotheses $\mathrm{H}_{3}-\mathrm{H}_{6}$. These illustrate that relationships between competitive strategy, operations practice, and operational performance, are not only a function of the strategy adopted, but that the impact of specific practices on performance is in several instances indirect in nature. This is significant for two reasons. First, it provides managers direction in how to deploy resources. For firms with a niche market focus, the implication is that strategy should drive internal manufacturing processes and efforts to integrate 
with suppliers. This is turn drives efforts to engage the workforce which directly influences performance. In contrast, for firms adopting a broad market focus, developing the human resource infrastructure should be the starting point in translating strategy to practice. Second, it highlights the need to view execution of strategy from an integrative perspective. In the case of a niche market focus for example, managing manufacturing processes alone is not what drives performance. Leveraging the workforce in a manner consistent with processes that reflect the firm's objectives in the market place, is what drives performance. This in turn suggests is the need to hire, train, motivate, and reward the workforce in a manner aligned with the firm's competitive focus.

The results are also important in that they provide evidence of the role of strategy and its execution via operations in a developing economy. Most of what is known about strategy, both at the corporate and operations levels comes from studies of highly developed economies such as those of the U.S., Japan, and Western Europe. As the economies of developing nations in Asia, South America, and Eastern Europe continue to expand and gain in sophistication, the importance of understanding what drives operational performance and improvement efforts in an emerging economy becomes of greater significance. This study provides specific insights into the relationships between market focus, process management, workforce commitment, relationship development, and operational performance for manufacturers in Thailand. Results suggest that firms wishing to enhance their performance should increase the implementation of the variables identified in tables 2 - 7. For example, to improve process management, firms should expand the use of quick changeover techniques, new process equipment and technologies, preventive maintenance, cycle time reduction, and error proofing techniques. 
While the results do not show process management and relationship development to be significant predictors of operational performance for firms with a niche market focus or workforce commitment to be a significant predictor of performance for firms with a broad market focus, they nevertheless play a vital role. The implication is that Thai firms must ensure that good process management, workforce commitment, and relationship development programs are in place. Using Skinner's analogy (1969), firms with a niche market focus that fail to recognize the effects of process management and relationship development, or those with a broad market focus that disregard the impact of workforce commitment, demonstrate a missing link between competitive strategy and performance. Failing to allocate adequate resources to any of these programs in a manner consistent with competitive strategy is likely to compromise operational performance.

The research is not without limitations. First, while this study involves a large sample study of manufacturing firms across several sectors, it is still based on firms in a single emerging economy. The results should thus not be generalized across manufacturers in developed nations. Moreover, there might be other contextual constructs that influence operational performance. The study also suffers from the usual pitfalls of empirical research, such as the reliance on a single respondent from a firm. This precluded assessment of inter-rater reliability. It also precluded analysis of the impact of variables such as country, industry, position in the supply chain, and relative power of supply chain participants on the research model. This however represents an opportunity for further research. 


\section{APPENDIX}

\section{A. Competitive Strategy - adapted from Liao and Cheung (2002)}

To what extent are the following practices/activities implemented in your company?

(I) Niche Market Focus

A2. The firm seeks to develop products with higher-added value focusing on specific markets and/or customer groups only.

A4. The firm seeks to supply products at lowest costs to specific markets and/or customer groups only.

A6. The firm seeks to differentiate products and supply specific markets and/or customer groups only.

\section{(II) Broad Market Focus}

A1. The firm seeks to develop products with higher-added value in a wide range of commercial and industrial uses.

A3. The firm seeks to supply products at lowest costs to a broad range of market segments.

A5. The firm seeks to differentiate products and supply to a broad range of market segments.

\section{B. Process Management (Lean Practices) - adapted from Shah and Ward (2003)}

To what extent are the following practices/activities implemented in your company?

B1. Implementing preventive maintenance activities

B2. Cycle time reduction

B3. Using new process equipment or technologies

B4. Using quick changeover techniques

B5. Using error proofing techniques/Poka-Yoke 


\section{Workforce Commitment (Soft TQM Practices) - adapted from Rahman and Bullock (2005)}

To what extent are the following practices/activities implemented in your company?

C1. Ideas and suggestions from production operators are actively used

C2. Has effective "top-down" and "bottom-up" communication

C3. Encourage change and a culture of trust and innovation

C4. The concept of the "internal customer" is well understood

C5. Unity of purpose and eliminated barriers between people

C6. Employee flexibility, multi-skilling and training are used

C7. All employees believe that quality is their responsibility

D. Relationship Development (Supply Chain Management Practices) -adapted from Tan (2001) To what extent are the following practices/activities implemented in your company?

D1. Determining customers' future expectation and needs

D2. To maintain close and good relationship with supplier

D3. To maintain close and good relationship with customer

D4. Using formal information sharing with suppliers and customers

D5. Creating a compatible information systems

D6. Communicating your future strategic needs to your suppliers and customers

D7. Involving customers and suppliers for work improvement in your firm

\section{E. Operational Performance - Adapted from Fynes, Voss and Búrca (2005)}

To what extent are your following business results compared with your competitors?

E1. Ability to delivery on time

E2. Overall efficiency

E3. Overall customer satisfaction 


\section{REFERENCE}

Anderson, J.C., Gerbing, D.W., 1988. Structural equation modeling in practice: A review and recommended two-step approach. Psychological Bulletin 103 (3), 411-423.

Anderson, J.C., Rungtusanatham, M., Schroeder, R.G., Devaraj S., 1995. Path analytic model of a theory of quality management underlying the Deming management method: preliminary empirical findings. Decision Sciences 26 (5), 637-658.

Bozarth, C.C., 1993. A conceptual model of manufacturing focus. International Journal of Operations \& Production Management 13 (1), 81-92.

Bozarth, C.C., Edwards, S., 1997. The impact of market requirements focus and manufacturing characteristics focus on plant performance. Journal of Operations Management 15 (3), 161180.

Bozarth, C.C., McCreery, J., 2001. A longitudinal study of the impact of market requirements focus on manufacturing performance. International Journal of Production Research 39 (14), 32373252.

Brown, S. , Squire, B., and Blackmon, K., 2007. The contribution of manufacturing strategy involvement and alignment to world-class manufacturing performance. International Journal of Operations \& Production Management 27(3), 282-302.

Carr, A.S., Pearson, J.N., 1999. Strategically managed buyer-supplier relationships and performance outcomes. Journal of Operations Management 17 (5), 497-519.

Cronbach, L.J., 1951. Coefficient alpha and the internal structure of tests. Psychometrika 16, 297334.

Davis, T., 1993. Effective supply chain management. Sloan Management Review 12, 35-46.

Dow D., Samson D., Ford S., 1999. Exploding the myth: do all quality management practices contribute to superior quality performance? Production and Operations Management 8 (1), $1-27$.

Flynn, B.B., Sakakibara, S., Schroeder, R.G., 1995a. Relationship between JIT and TQM: practices and performance. Academy of Management Journal 38 (5), 1325-1360.

Flynn, B.B., Schroeder, R.G., Sakakibara, S. 1995b. The impact of quality management practices on performance and competitive advantage. Decision Sciences 26, 659-692.

Fullerton, R.R., McWatters, C.S., 2001. The production performance benefits from JIT implementation. Journal of Operations Management 19 (1), 81-96.

Fynes B., Voss C., Búrca S.D., 2005. The impact of supply chain relationship dynamics on manufacturing performance. International Journal of Operations \& Production Management 25 (1), 6-19.

Hayes, R.H., Schmenner, R.W., 1978. How should you organize manufacturing? Harvard Business Review 56 (1), 105-118. 
Hayes, R.H., Wheelwright, S.C., 1979. Link manufacturing process and product life cycles. Harvard Business Review 57 (1), 133-140.

Kaiser, H.F., 1974. An index of factorial simplicity. Psychometrika 39, 31-36.

Kannan, V.R., Tan, K.C., 2005. Just in time, total quality management, and supply chain management: understanding their linkages and impact on business performance. Omega: The International Journal of Management Science 33, 153-162.

Karim, M. A., Smith, A.J.R., and Halgamuge, S. 2008. Empirical relationships between some manufacturing practices and performance. International Journal of Production Research 46(13), 3583-3613.

Kochan, T.A., Gittel, J.H., Lautsch, B.A., 1995. Total quality management and human resource systems: an international comparison. The International Journal of Human Resource Management 6 (2), 201-222.

Laosirihongthong, T., Dangayach, G.S., 2005. A comparative study of implementation of manufacturing strategies in Thai and Indian automotive manufacturing companies. Journal of Manufacturing Systems 24 (2), 131-143.

Laosirihongthong, T., Paul, H., Speece, M.W., 2003. Evaluation of new manufacturing technology implementation: an empirical study in the Thai automotive industry. Technovation 23 (4), 321-332.

Liao Z., Cheung M.T., 2002. Do competitive strategies drive R\&D? An empirical investigation of Japanese high-technology corporations. Journal of High Technology Management Research 13, 143-156.

Martin, J.H., Grbac, B., 2003. Using supply chain management to leverage a firm's market orientation. Industrial Marketing Management 32 (1), 25-38.

Miller, D., 1988, Retailing Porter's business strategies to environment and structure: analysis and performance implications. Academy of Management Journal 31 (2), 280-308.

Nakamura, M., Sakakibara, S., Schroeder, R.D., 1998. Adoption of just in time manufacturing methods at U.S. and Japanese owned plants: some empirical evidence. IEEE Transactions on Engineering Management 45 (3), 230-240.

Nunnally, J., 1988. Psychometric Theory. McGraw-Hill, New York, NY.

Phusavat, K., Kanchana, R., 2008. Future competitiveness: viewpoints from manufacturers and service providers. Industrial Management \& Data Systems 109 (2), 191-207.

Podsakoff, P.M., Mackenzie, S.B., Lee, J.Y., Podsakoff, N.P., 2003. Common method biases in behavioral research: a critical review of the literature and recommended remedies. Journal of Applied Psychology 88 (5), 879-903.

Porter, M.E., 1980. Competitive Strategy. New York: Free Press.

Power, D.J, Amrik, S.S., Rahman, S., 2001. Critical success factors in agile supply chain management. International Journal of Physical Distribution and Logistics Management 31 (4), 247-265. 
Rahman, S., Bullock, P., 2005. Soft TQM, hard TQM, and organisational performance relationships: an empirical investigation. Omega: The International Journal of Management Science 33, 73-83.

Sakakibara, S., Flynn, B.B., Schroeder, R.G., Morris, W.T., 1997. The impact of just-in-time manufacturing and its infrastructure on manufacturing performance. Management Science $43(9), 1246-1257$.

Samson, D., Terziovski, M., 1999. The relationship between total quality management practices and operational performance. Journal of Operations Management 17 (4), 393-409.

Shah, R., Ward, P. T., 2007. Defining and developing measures of lean production. Journal of Operations Management 25, 785-805.

Shah, R., Ward, P.T., 2003. Lean manufacturing: context, practice bundles and performance. Journal of Operations Management 21, 129-149.

Skinner, W., 1969. Manufacturing - missing link in corporate strategy. Harvard Business Review 46 (3), 136-145.

Skinner, W., 2007. Manufacturing strategy: the story of its evolution. Journal of Operations Management 25 (2), 328-335.

Swink, M., Narasimhan, R., and Kim, S.W., 2005. Manufacturing practices and strategy integration: Effects of cost efficiency, flexibility, and market-based performance. Decision Science 36 (3), 42-457.

Tan, K. C., 2001. A framework of supply chain management literature. European Journal of Purchasing \& Supply Management 7 (1), 39-48.

Tan, K. C., 2002. Supply Chain Management: practices, concerns, and performance issues. The Journal of Supply Chain Management 38 (1), 42-53.

Tata, J., Prasad, S., Thorn, R., 1999. The influence of organizational structure on the effectiveness of TQM programs. Journal of Managerial Issues 11 (4), 440-453.

Wang, T.Y., Chien, S.C., 2007. The influences of technology development on economic performance - the example of ASEAN countries. Technovation 27, 471-488.

Ward, P.T., Brickford, D.J., Leong, G.K., 1996. Configurations of manufacturing strategy, business strategy, environment and structure. Journal of Management 22 (4), 597-626.

Ward, P.T., Duray, R., 2000. Manufacturing strategy in context: environment, competitive strategy and manufacturing strategy. Journal of Operations Management 18 (2), 123-138.

Womack, J.P., Jones, D.T., Roos, D., 1990. The Machine That Changed the World. Harper Perennial, New York, NY. 


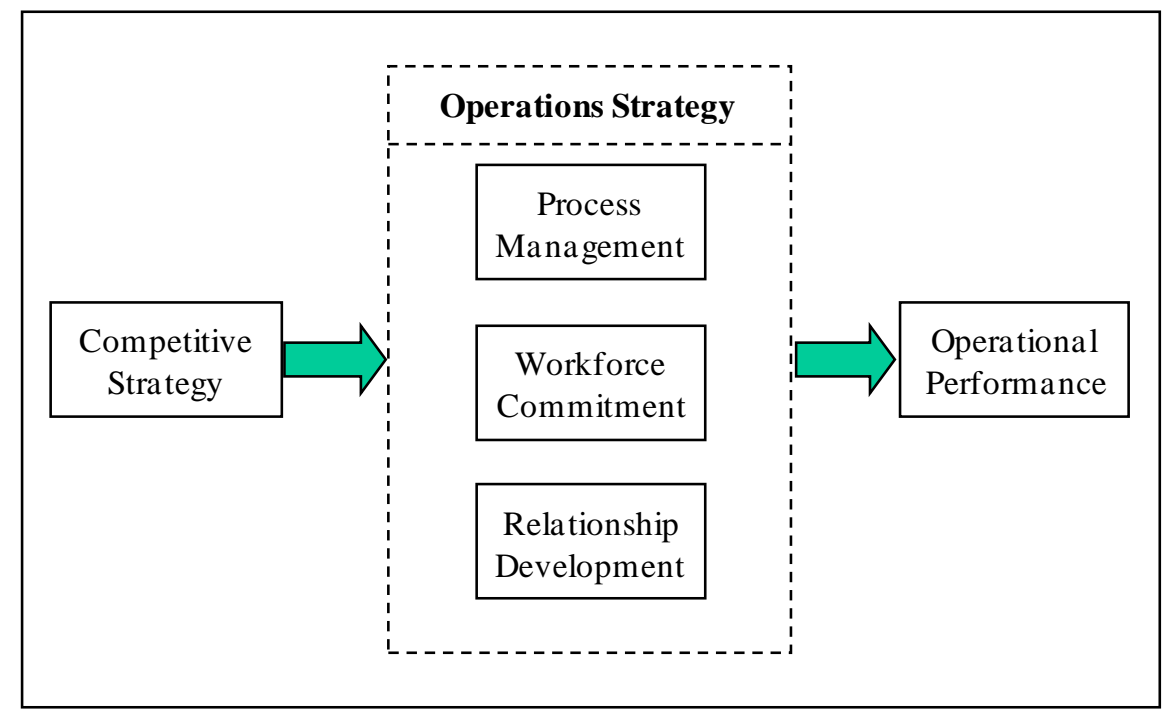

Figure 1: Research Framework

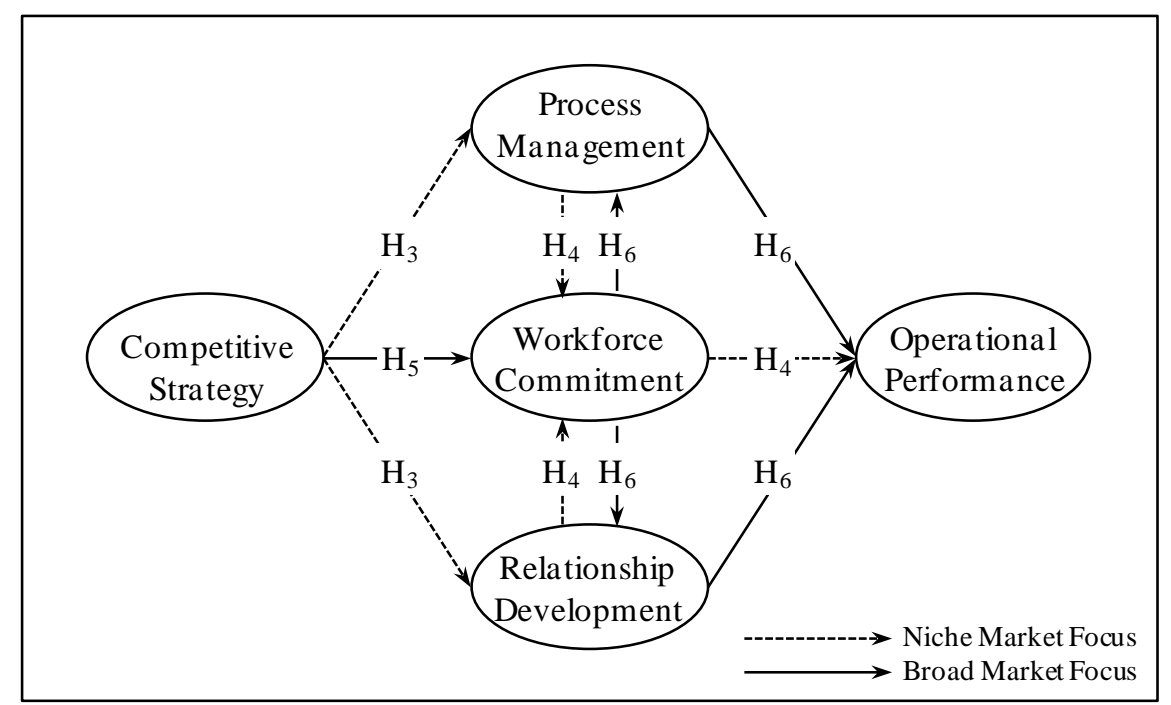

Figure 2: Proposed Structural Equation Model 


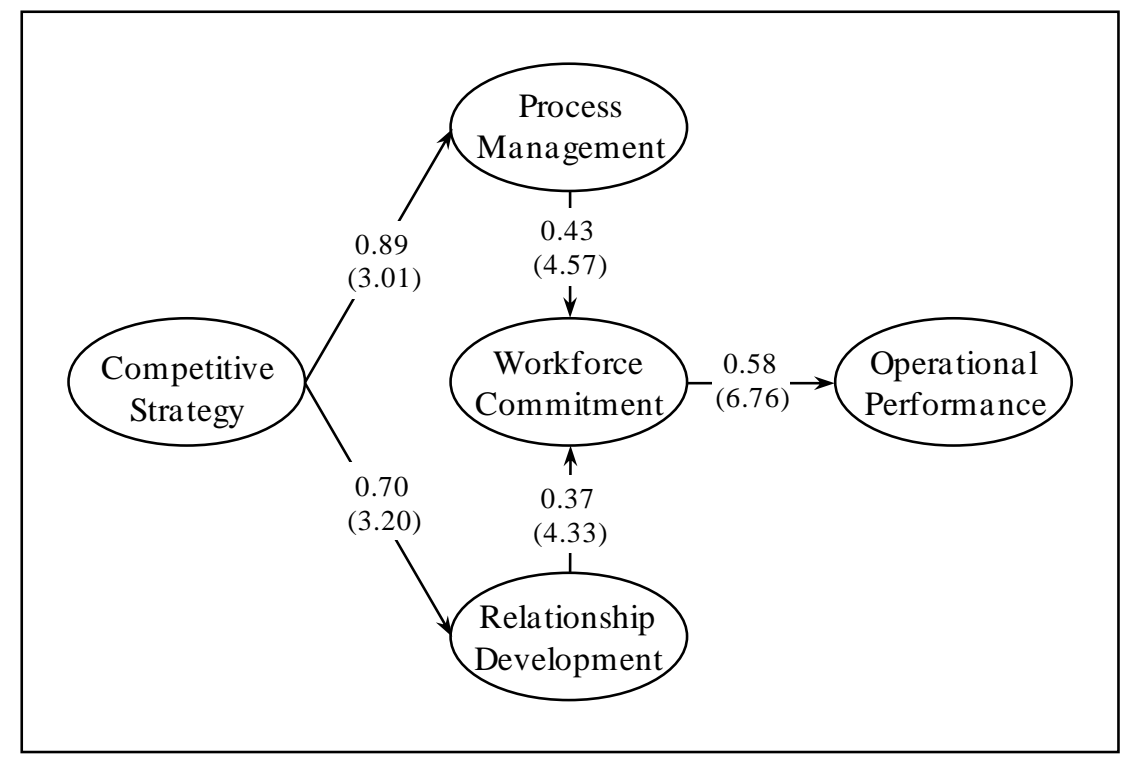

Figure 3: Structural Equation Model for Niche Market Focus Cluster

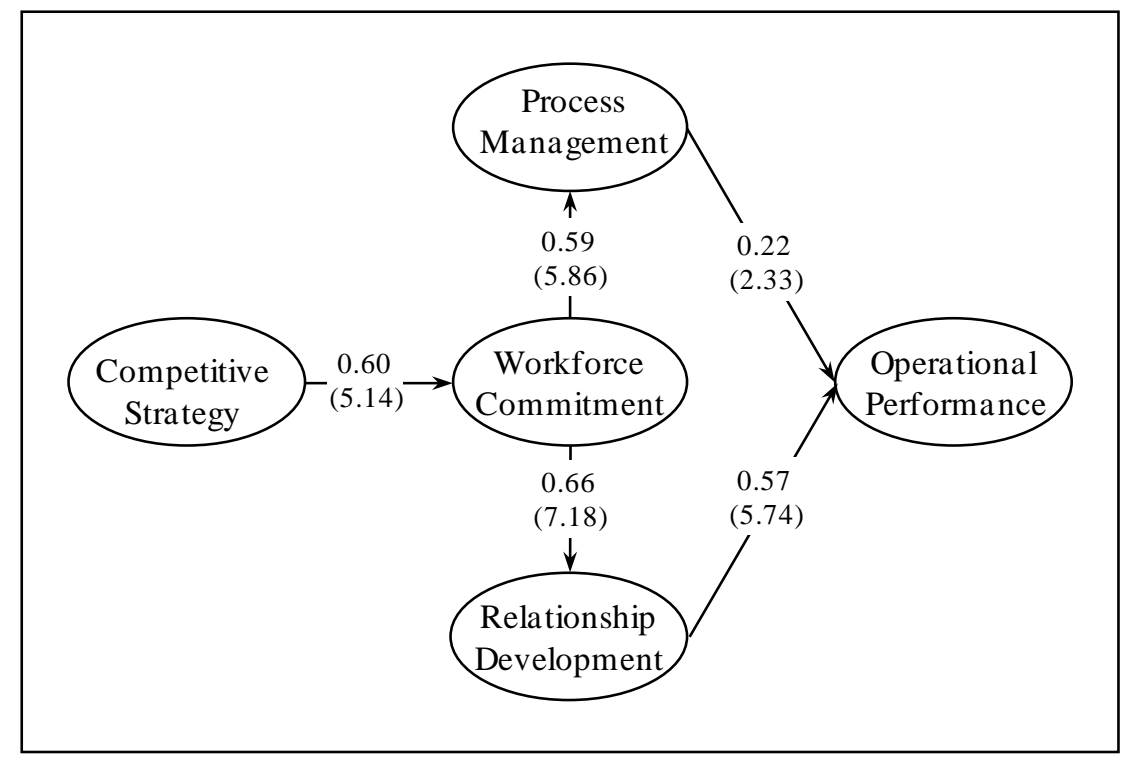

Figure 4: Structural Equation Model for Broad Market Focus Cluster 
Table 1: Respondent Profile

\begin{tabular}{|l|l|r|}
\hline Characteristics of Respondent (Sample Size, $\mathbf{n}=\mathbf{3 2 9}$ ) & Frequency \\
\hline \multirow{3}{*}{ Number of Employees } & $1-200$ & 68 \\
& More than 200 & 258 \\
& Missing response & 3 \\
\hline & Less than 2 years & 74 \\
Years of Working Experience & $2-5$ years & 117 \\
& $5-10$ years & 82 \\
& More than 10 years & 50 \\
& Missing response & 6 \\
\hline Type of Ownership & Joint Venture & 123 \\
& Foreign-Owned & 129 \\
& Thai-Owned & 65 \\
& Missing response & 12 \\
\hline & Automotive & 115 \\
Industry Classification & Electronic & 81 \\
& Food & 16 \\
& Textile & 18 \\
& Chemical & 47 \\
& Construction & 49 \\
& Missing Response & 3 \\
\hline Type of International Standards for & ISO 9001 & 247 \\
Management Systems Adopted & ISO 14001 & 208 \\
(Majority of the responding firms adopted & ISO/TS 16949 & 94 \\
more than one type of standards) & Others & 68 \\
\hline
\end{tabular}


Table 2: Niche Market Focus Competitive Strategy

\begin{tabular}{|l|c|}
\hline $\begin{array}{l}\text { Focus of Niche Market Competitive Strategy (Cronbach's } \alpha=.661 ; \text { Composite Reliability }= \\
.817 ; \text { Average Variance Extracted }=.598 ; \text { Variance Explained }=59.77 \%)\end{array}$ & Loadings \\
\hline $\begin{array}{l}\text { A4. The firm seeks to supply products at lowest costs to specific markets and/or customer } \\
\text { groups only. }\end{array}$ & .775 \\
\hline $\begin{array}{l}\text { A6. The firm seeks to differentiate products and supply specific markets and/or customer } \\
\text { groups only. }\end{array}$ & .775 \\
\hline $\begin{array}{l}\text { A2. The firm seeks to develop products with higher-added value focusing on specific } \\
\text { customer groups only. }\end{array}$ & .770 \\
\hline $\begin{array}{l}\text { Kaiser-Meyer-Olkin Measure of Sampling Adequacy } \\
\text { Bartlett's Test of Sphericity: Approx. Chi-Square }\end{array}$ & .661 \\
\hline df & 136.471 \\
\hline
\end{tabular}

Table 3: Broad Market Focus Competitive Strategy

Focus of Broad Market Competitive Strategy (Cronbach's $\alpha=.813$; Composite Reliability = .890; Average Variance Extracted $=.731$; Variance Explained $=73.05 \%$ )

A1. The firm seeks to develop products with higher-added value for a wide range of commercial and industrial uses.

A3. The firm seeks to supply products at lowest costs to a broad range of market segments.

A5. The firm seeks to differentiate products and supply a broad range of market segments.

Kaiser-Meyer-Olkin Measure of Sampling Adequacy

Bartlett's Test of Sphericity: Approx. Chi-Square

df

Sig.73.05

Loadings

Table 4: Process Management (Lean Practices)

Process Management Practices (Cronbach's $\alpha=.835$; Composite Reliability = .884; Average

Variance Extracted $=.605$; Variance Explained $=60.50 \%$ )

B4. Using quick changeover techniques

B3. Using new process equipment or technologies

B1. Implementing preventive maintenance activities

B2. Cycle time reduction

B5. Using error proofing techniques/Pokayoke

Kaiser-Meyer-Olkin Measure of Sampling Adequacy

Bartlett's Test of Sphericity: Approx. Chi-Square

$\mathrm{df}$

Sig. 60.5

Loadings 
Table 5: Workforce Committee (Soft TQM)

\begin{tabular}{|l|c|}
\hline Workforce Commitment Practices (Cronbach's $\alpha=.889 ;$ Composite Reliability =.914; & Loadings \\
Average Variance Extracted = .604; Variance Explained =60.43\%) & .831 \\
\hline C3. Encourage change and a culture of trust and innovation & .825 \\
C5. Unity of purpose and eliminated barriers between people & .792 \\
C4. The concept of the "internal customer" is well understood & .780 \\
C2. Has effective "top-down" and "bottom-up" communication & .754 \\
C7. All employees believe that quality is their responsibility & .728 \\
C1. Ideas from production operators suggestion are actively used & .725 \\
C6. Employee flexibility, multi-skilling and training are used & .896 \\
\hline Kaiser-Meyer-Olkin Measure of Sampling Adequacy & 1131.458 \\
\hline Bartlett's Test of Sphericity: Approx. Chi-Square & 21 \\
\hline df & .000 \\
\hline
\end{tabular}

Table 6: Relationship Management (Supply Chain Management Practices)

Relationship Management Practices (Cronbach's $\alpha=.904$; Composite Reliability = .926; Average Variance Extracted $=.641$; Variance Explained $=64.07 \%$ )

D4. Using formal information sharing with suppliers and customers

D2. To maintain close and good relationship with supplier

D3. To have closely activities for good relationship with customer

D6. Communicating your future strategic needs to your suppliers and customers

D5. Creating the compatible information systems

D7. Involving all members by representative of firm, customer \& suppliers for work improvement

D1. Determining customers' future expectation and needs

Kaiser-Meyer-Olkin Measure of Sampling Adequacy

Bartlett's Test of Sphericity: Approx. Chi-Square

df

Sig.64.07

Loadings

.850

.840

.824

.800

.799

.759

.723

.890

1345.664

21

.000

Table 7: Operational Performance

\begin{tabular}{|l|c|}
\hline Operational Performance (Cronbach's $\alpha=.754$; Composite Reliability $=.866 ;$ Average & Loadings \\
Variance Extracted = .683; Variance Explained =68.25\%) & .874 \\
\hline E2. Overall efficiency & .851 \\
E3. Overall customer satisfaction & .749 \\
E1. Ability to delivery on time & .660 \\
\hline Kaiser-Meyer-Olkin Measure of Sampling Adequacy & 272.344 \\
\hline Bartlett's Test of Sphericity: Approx. Chi-Square & 3 \\
\hline df & .000 \\
\hline
\end{tabular}


Table 8: Centroid Method Hierarchical Cluster Analysis - Descriptive Statistics

\begin{tabular}{|ll|r|r|r|r|}
\hline & Frequency & Percent & Valid Percent & $\begin{array}{r}\text { Cumulative } \\
\text { Percent }\end{array}$ \\
\hline \multirow{3}{*}{ Valid } & 1 & 185 & 56.2 & 57.6 & 57.6 \\
& 2 & 136 & 41.3 & 42.4 & 100.0 \\
Missing & Total & 321 & 97.6 & 100.0 & \\
Total & & 8 & 2.4 & & \\
\hline
\end{tabular}

Table 9: Group Statistics and Independent t-test of Broad versus Niche Market Focus

\begin{tabular}{|c|c|c|c|c|c|c|c|c|}
\hline \multirow{2}{*}{\multicolumn{2}{|c|}{ Competitive strategy }} & \multirow{2}{*}{$\mathrm{N}$} & \multirow{2}{*}{ Mean } & \multirow{2}{*}{$\begin{array}{l}\text { Std. } \\
\text { Dev. }\end{array}$} & \multirow{2}{*}{$\begin{array}{l}\text { Std. Error } \\
\text { Mean }\end{array}$} & \multicolumn{3}{|c|}{ Independent t-test } \\
\hline & & & & & & $\mathrm{t}$ & df & Sig (2-tailed) \\
\hline \multirow{2}{*}{$\begin{array}{l}\text { Niche Market Focus } \\
\text { (Cluster } 1 \text { ) }\end{array}$} & Cluster 1 & 185 & .3004 & .8220 & .0604 & \multirow{2}{*}{6.626} & \multirow{2}{*}{319} & \multirow{2}{*}{.000} \\
\hline & Cluster 2 & 136 & -.4033 & 1.0806 & .0927 & & & \\
\hline \multirow{2}{*}{$\begin{array}{l}\text { Broad Market Focus } \\
\text { (Cluster } 2 \text { ) }\end{array}$} & Cluster 1 & 185 & -.4755 & .9400 & .0691 & \multirow{2}{*}{-11.862} & \multirow{2}{*}{319} & \multirow{2}{*}{.000} \\
\hline & Cluster 2 & 136 & .6439 & 6669 & .0572 & & & \\
\hline
\end{tabular}

Table 10: Descriptive Statistics of the Clusters

\begin{tabular}{|c|c|c|c|c|c|c|}
\hline \multirow{2}{*}{ Competitive strategy } & \multicolumn{2}{|c|}{ Cluster 1, N=185 } & \multicolumn{2}{c|}{ Cluster 2, N = 136 } \\
\cline { 2 - 6 } & Mean & Std Error & Std Dev & Mean & Std Error & Std Dev \\
\hline $\begin{array}{c}\text { A2. Develop products with higher-added value } \\
\text { focusing on specific customer groups only }\end{array}$ & $\mathbf{4 . 1 4 *}$ & .078 & 1.059 & 2.93 & .105 & 1.221 \\
\hline $\begin{array}{c}\text { A4. Supply products at lowest costs to specific } \\
\text { markets and/or customer groups only }\end{array}$ & $3.60^{*}$ & .103 & 1.400 & 2.80 & .101 & 1.179 \\
\hline $\begin{array}{c}\text { A6. Differentiate products and supply specific } \\
\text { markets and/or customer groups only }\end{array}$ & $3.26 *$ & .101 & 1.367 & 3.13 & .106 & 1.238 \\
\hline $\begin{array}{c}\text { A1. Develop products with higher-added value } \\
\text { and wide range of commercial and } \\
\text { industrial uses }\end{array}$ & 2.95 & .108 & 1.473 & $4.14 *$ & .079 & .920 \\
\hline $\begin{array}{c}\text { A3. Supply products at lowest costs to a broad } \\
\text { range of market segments }\end{array}$ & 2.63 & .100 & 1.362 & $3.93^{*}$ & .089 & 1.034 \\
\hline $\begin{array}{c}\text { A5. Differentiate products and supply a broad } \\
\text { range of market segments }\end{array}$ & 2.39 & .086 & 1.175 & $3.85^{*}$ & .091 & 1.060 \\
\hline
\end{tabular}

* indicates statistically higher mean value at $\alpha=5 \%$. 
Table 11: Multiple Linear Regression Models

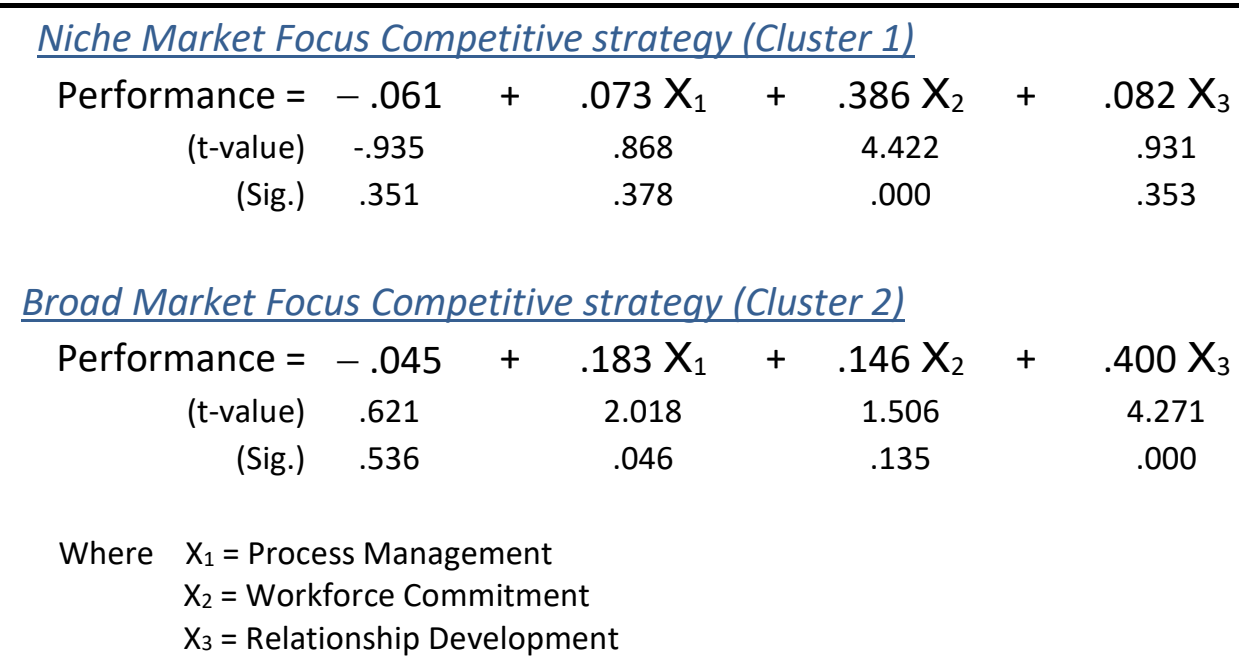

Table 12: Fit Indices for Niche and Broad Market Focuses

\begin{tabular}{|c|c|c|}
\hline GOODNESS OF FIT STATISTIC & Niche MARKet Focus & BROAD MARKET FOCUS \\
\hline$\chi^{2} /$ degrees of freedom $\left(\chi^{2} / \mathrm{df}\right)$ & 1.3247 & 1.4064 \\
\hline RMSEA & 0.042 & 0.055 \\
\hline$p$-value for $($ RMSEA $<0.05)$ & 0.87 & 0.26 (too low) \\
\hline GFI & 0.87 & 0.82 \\
\hline AGFI & 0.84 & 0.78 \\
\hline $\mathrm{NFI}$ & 0.95 & 0.92 \\
\hline NNFI & 0.98 & 0.97 \\
\hline $\mathrm{CFI}$ & 0.98 & 0.97 \\
\hline IFI & 0.98 & 0.97 \\
\hline $\mathrm{RFI}$ & 0.94 & 0.91 \\
\hline
\end{tabular}

